\title{
Cultural Roots of Seafarers in Tuju-Tuju Harbor, Bone Regency, Sulawesi Selatan, Indonesia
}

\author{
Amirullah* \\ Departemen of History Education \\ Faculty of Social Science \\ Universitas Negeri Makassar \\ Makassar, Indonesia \\ Amirullah8505@unm.ac.id
}

\author{
Rifal \\ Departemen of History Education \\ Faculty of Social Science \\ Universitas Negeri Makassar \\ Makassar, Indonesia \\ rifalmattirodeceng@gmail.com
}

\begin{abstract}
The Bugis are known as accomplished seamen. Most of the coast of the archipelago found Bugis settlements, through the sea they became a transfer of the nautical culture of the archipelago. By presenting a fairly long historical experience, delivering Bugis as human beings who have a tested and experienced work culture. These values continue to radiate in the Bugis human life in shipping activities undertaken. The cultural process of cultural socialization of the Bugis is rooted in the total results and behavior possessed by the Bugis Makassar community and can be continued from generation to generation through the learning process. These results are Bugis-Makassar cultural values that have been embodied in the behavior patterns of the Bugis-Makassar people in their daily lives. Makassar Bugis cultural values are as follows: the value of loyalty, the value of courage, the value of valuation, work ethic, mutual cooperation, determination, solidarity, unity, harmony, and deliberation. This research is an anthropological soiology study using qualitative qualifications. Data obtained through interviews collected with secondary data relevant to the research theme. Furthermore, research that reviews the situation or situation that will be examined based on data obtained in accordance with the problems specified in the research.
\end{abstract}

\section{Keywords: Work Culture, Seafarers, Tuju-Tuju Port}

\section{INTRODUCTION}

The Bugis community, has always been known to have a system of life and values that they guide in family life and society. The main values of the Bugis culture include honesty (talu '), scholarship (amaccang), propriety (assitinajang), determination (agettengeng), effort (reso), principle of shame (siri') [1]. The culture of the people of South Sulawesi has been recorded in ancient Bugis (also Makassar) literature called "Lontarak", in which there are teachings that tell about the origin of human events, the occurrence of kingdoms, rules of human life, etc. other. Since pre-Islamic times until now this can be expressed through written sources since the XIV century AD until the acceptance of Islam as a religion adopted by the community in the early XVII century AD. During that time, the only source that described the Bugis community was Lontarak [2]-[4].

In maritime culture, this culture is still held by sailors. In this case, seafarers are one of the maritime sector jobs that has a great influence on the life of shipping in Indonesia. Every ship that sails holds a great responsibility both to the crew, passengers and cargo carried. In addition, the vast ocean terrain (even ships that sail between oceans), the challenges of changing weather while sailing and various other extreme factors make the profession of a sailor very risky, therefore it is not uncommon for jobs as a sailor to have to bet with lives. Various obstacles for seafarers' work while sailing can of course be minimized with a variety of early prevention and maximum protection when seamen work both outside and / or on the ship. Therefore, it is very important for the government to provide a certain standardization for seafarers so that they can work in a conducive, safe and secure manner. Conducive in the sense that there is a good environment available for seafarers so that seafarers can focus on sailing, safe means there is protection for seafarers and ships so that they can sail freely without disturbances so that they get to their destination, while being guaranteed means there is full protection in the form of a guarantee of the return of seafarers to the place of origin after carrying out his duties sailing to the destination. Working in a conducive, safe and secure manner is the right of seamen. The realization of seafarers 'rights is very important and is closely related to the welfare of seafarers because the more comprehensive the standards set for seafarers, the more embodiment of seafarers' rights will be fulfilled. The welfare of seafarers is also closely related to the quality and quantity of seafarers in Indonesia. Conducive, safe and secure working conditions when sailing will be directly proportional to the better quality of seafarers' work. The higher the quality of seafarers' work, the level of community interest to become seafarers will also be higher so that in the end it will affect the quantity of seafarers in Indonesia more and more [5].

Seafarers as maritime workers are becoming something unusual. They must have strong mentality and values. This value is a part that affects the mental of seamen. Therefore, it is necessary to discuss more deeply related to the cultural background of seafarers' work. Why do they survive with great safety and health risks while still working as sailors. What actually caused them to survive? As stated before, the values of the Bugis are internalized in all aspects of human life, in various fields, especially in the maritime field. The cultural diversity of the South Sulawesi region, among others in the form of historical relics, traditions, and customs, One of the historical heritages that holds various aspects of ethnic culture that has its own script is a script. In this world, not all ethnic groups have their own characters. The Bugis are one of the ethnic groups that are fortunate to have characters so that aspects of culture in the past can still be stored in the 
Lontara 'text. One form of the Lontara 'Bugis manuscript that deals with wisdom and is loaded with values and characters is known as the Pappasen (Messages; advice; wills; mandate) [6].

\section{METHOD}

This research uses a descriptive type qualitative approach. Bogdan and Taylor define qualitative methodology as a research procedure that produces descriptive data in the form of written or oral words from people and observed behavior [7]-[10]. The place of research is the object and source of data from a careful place so that the information obtained can provide accurate data and truth in research. In this study, taking location in the Regency of Bone precisely in the Port of Tuju-Tuju and surrounding areas. When viewed from the data source, the data collection can use primary data sources and secondary data sources.

Data collection techniques are an attempt to observe the variables studied through certain methods. The method that researchers use as follows:

\section{a. Observation}

Observation or observation is a direct and systematic observation activity carried out at the study site. The author observes the parties who become informants in the study based on predetermined criteria.

\section{b. Interview}

Interview or interview used is a form of verbal communication. So, a kind of conversation aimed at obtaining information about the research topic. The interview process can be carried out by both parties, namely the interviewer and the interviewee. The interview method used in this study aims to obtain information verbally from seafarers operating in the Port of Tuju-tuju. Interviews were conducted freely to obtain more data and to avoid confusion in obtaining information. The contents of the interview were based on the problems in this study.

\section{c. Documentation}

The document is a record of events that have already passed. Documentation is a data collection technique by collecting and analyzing documents, both written documents, images and electronics. Documentation can be a complement to the use of observation and interview methods in qualitative research.

Data analysis in this research was carried out since before entering the field, during the field, and after completion in the field. Data obtained from the field are then processed descriptively qualitatively through three stages, namely data reduction, data presentation and drawing conclusions.

\section{RESULT AND DISCUSSION}

Job success is rooted in a work culture that is built from the strength of the values held by the community. It departs from habits, religion and norms that become habits that have become culture. In this section, work culture will be directed at the lives of seamen in Tuju-tuju, Bone Regency. To deepen, it is first translated into the concept of work culture itself.

The word culture itself is a development of the Sanskrit language 'Buddhism' which is the plural form of buddhi or reason, and compound words cultivation, which means the power of mind, in other words' culture is the power of mind in the form of creativity, intention and taste. While culture is the development of culture that is the result of copyright, intention and taste "[11]. The notion of culture is raised by many experts such as Koentraningrat, namely; "Culture is the whole human being from the behavior and the results of the behavior that is organized by the behavior that must be obtained by learning and everything is arranged in people's lives" [12], [13].

Work culture, is a group of behavior patterns that are inherent as a whole in each individual. Building culture means also increasing and maintaining the positive sides, as well as trying to familiarize (habituating process) certain patterns of behavior in order to create a new form that is better. In the form of philosophy which is based on the view of life as values that become the nature, habits, and driving forces, entrenched in the life of a community or organization that is reflected in attitudes into behavior, beliefs, ideals, opinions and actions that manifest as work or work [14]. Conceptually, a work culture can be described intellectually as follows: First, conceptually, the textual work culture can be described, namely: a. Integrity and professionalism, which is consistent in words and deeds as well as experts in their fields. People who have personality integrity, then he will do something in accordance between what was said and what was done. This personality emerges from the belief that work is not merely to achieve worldly achievements but also has a meaning of horizon or worship. Work based on the spirit of worship will cause people to work selflessly for the benefit of individuals but for the benefit of togetherness. It also has a balanced ability. He will work with his knowledge, attitude and expertise.

Second, leadership and role models, which are able to utilize the potential abilities of subordinates optimally. If accuracy is given the power to become a leader then it will not use it to work authoritatively but in a participatory manner. Someone will maximally utilize his subordinates as partners to achieve the vision and mission of the institution. It also applies as an example. Be a role model in hard work, responsibility, and discipline and so on. As the Prophets exemplified in the sacred text that "in the Prophet himself is a good example and example". Real leaders are the inheritors of true role models in this life. Third, togetherness and group dynamics, which encourages the way of working not to have individual characteristics and the center of power is not in one hand. Something that is very difficult in working relationships is to build cooperation in group work. Even though humans know that it is impossible to deal with matters individually, but when they have to work together sometimes have difficulties. Just imagine there is no human 
being who can meet his own needs except in his relationships with other humans. There is a good phrase that is TEAM, Together Everyone Achieve More. It is precisely through togetherness someone will get more.

Fourth, the accuracy and speed, namely the certainty of time, quantity, quality and financial needed. The principle that must serve as a guideline is the sooner the better. The principle of service that must be developed in an institution is excellent service based on speed and accuracy. Not the principle of gremet-gremet angger slamet or slowly but survived, but quickly angger selamet quickly. So what is needed is speed and accuracy. Fast and precise work is work that uses clear measurements. If the work can be completed in one day, it will be finished on time. If the work consumes a certain budget, it will be carried out according to the right budget size. If it can be like that then there will be no cases of mark ups and so on, nor is it work that makes something easy become difficult and so on.

Fifth, rationality and emotional intelligence, which is a balance between intellectual and emotional intelligence. It turns out that in this life what is needed is not just an intellectual person. In fact, there are many people who are intellectually intelligent, but actually do not succeed in life. This life requires not only logic but also emotional intelligence based on an understanding of feelings and humanity [15], [16]. Through a balance between intellectual and emotional intelligence, it will bring up firmness and firmness. And what should not be forgotten is spiritual intelligence based on the beliefs and morality of goodness. By combining all three in work, a person will be able to achieve adequate happiness. Taliziduhu Ndraha in the book Theory of Work Culture, defines work culture, namely; "Work culture is a group of basic thoughts or mental programs that can be utilized to improve work efficiency and human cooperation owned by a group of people [17].

Therefore, it can be concluded that work culture is a philosophy as values that become the nature, habits, and driving forces that are shared by each individual in the work environment of an organization. Work culture differs from one organization to another, it is because the foundation and attitude of behavior that is reflected by everyone in the organization is different. Work culture that is formed positively will be beneficial because each member in an organization needs to contribute suggestions, opinions and even constructive criticism from the scope of work to progress in the educational institution, but the work culture will be bad if employees in an organization issue different opinions that is because there are differences in each individual in issuing opinions, energy and thoughts, because each individual has the ability and expertise according to their respective fields [15]. In the understanding of the Bugis, as for advice that is often recommended to the peluat to remain held firm, among others: first, always do good. In every human being there is always a virtue, where when humans have made their choices to something that is right then he will still hold fast to his choices. These ideals can be realized through the process of cultural democratization and selectively controlled processes, a process that has the substance of freedom and autonomy while being controlled with fundamental reference values and has been tested in the course of the times. As written in the pappaseng quote; you will receive the consequences later, because good deeds are affected by bad deeds. People who have bad intentions as a result will arrive at the offspring of that evil. Lontara's quote above emphasizes the importance of an individual to maintain the direction of his heart. Humans are required to always have good intentions towards others. Keeping the heart to always be clean hearted to fellow humans will lead the individual to pick the fruits of goodness. On the other hand, dirty-hearted individuals, who want bad things towards their fellow humans, will only receive bad consequences. Therefore, there is no reason for an individual to think bad things about his fellow humans. In other words, so that each individual can reap a fortune or success in living according to his ideals, he must first guard his heart from deviations. If you want someone to do good to him, he must first intend and do good to that person [18], [19].

Second, the value of honesty. Honesty is a basic foundation in establishing relationships with fellow human beings and is one of the very basic factors in human life. Honesty should not be considered ordinary, even underestimated in social life. Honesty should always be preserved and applied in everyday life. One of the causes of imbalance in society is that the values of honesty are not applied. Though being honest is a must for every individual. In Pappaseng it is stated as follows: Do not be left by skill and honesty. The so-called skillful, there is nothing difficult to do, there is also no conversation that is difficult to be greeted with kind words and gentle, trusting fellow human beings. The so-called honest; good deeds, right thoughts, good behavior, and fear of God. In the pappaseng it was explained that skills and honesty should go hand in hand and support one another. Skills without honesty are like ships without Nakoda, whereas honesty without skills is like Nakoda without ships [19].

Third, the value of independence. Independent is the attitude and behavior that is not easy to depend on others in completing tasks. This attitude of independence is strongly emphasized in the wisdom of the Bugis, as mentioned in this pappaseng: Saying (messages) the previous king to his grandchildren, to his relatives. If you are looking for sustenance, wait for the grace of Allah Ta'ala rather than the compassion of the ruling king, as well as in the business of planting. Likewise with your own efforts. The purpose of this message is to try to independently seek sustenance with one's own sweat, such as becoming a farmer, while farming is always praying and hoping for mercy from Allah Ta'ala so that the efforts made get blessings from Him. Working while praying is more noble than hoping for mercy from others [20], [21]. Four, Hard Work. Hard work is a serious effort to overcome various obstacles and problems in life. Such behavior has been instilled in Bugis culture. Do not want to be preceded setting foot at the end of the footbridge In trying, work should be maximized and clever to see business opportunities. This shows that in the effort required attention 
and competitive hard work [21], [22]. From this place became the cultural roots of Bugis sailors' work in navigating the ocean.

\section{CONCLUSION}

With a fairly long historical experience, delivering Bugis as a human who has a tested and experienced work culture. These values continue to radiate in the Bugis human life in shipping activities undertaken. The Bugis cultural cultural socialization process is rooted in the totality of the results of thought and behavior possessed by the Makassar Bugis community and can be continued from generation to the next generation through the learning process. The results of these thoughts are in the form of Bugis-Makassar cultural values that have been embodied in the behavior patterns of the Bugis-Makassar people in their daily lives. Makassar Bugis cultural values are as follows: the value of loyalty, the value of courage, the value of wisdom, work ethic, mutual cooperation, determination, solidarity, unity, harmony, and deliberation.

\section{ACKNOWLEDGMENT}

We thank you very much to Makassar State University, Faculty of Social Sciences for sponsoring the writing of this article. To the informants, especially the Juragan, Jurumudi, BAS and Tuju-Tuju Port Laborers who provided valuable information on this research.

\section{REFERENCES}

[1] A. R. Rahim, Nilai-nilai utama kebudayaan Bugis. Ombak, 2011.

[2] H. A. Mattulada, "South Sulawesi, Its Ethnicity and Way of Life," Southeast Asian Stud., vol. 20, no. 1, pp. 4-22, 1982.

[3] Mattulada, Sejarah, masyarakat, dan kebudayaan Sulawesi Selatan. Hasanuddin University Press, 1998.

[4] M. Yusuf, "Relevansi Nilai-Nilai Budaya Bugis dan Pemikiran Ulama Bugis: Studi Tafsir Berbahasa Bugis Karya MUI Sulsel," EL HARAKAH, vol. 15, no. 2, pp. 199-216, 2013.

[5] D. P. Yuda, "Perlindungan Hukum Bagi Tenaga Kerja Pelaut Dengan Sistem Kontrak.” Fakultas Hukum UNISSULA, 2017.

[6] N. Nurhaeda, "Revitalisasi nilai-nilai 'Pappaseng'sebagai kearifan lokal masyarakat Bugis: Konseling Eksistensial," in Prosiding Seminar Nasional Bimbingan dan Konseling, 2018, vol. 2, no. 1, pp. 295-313.

[7] A. B. Apolo et al., "Summary of the 8th Annual Bladder Cancer Think Tank: collaborating to move research forward," in Urologic Oncology: Seminars and Original Investigations, 2015, vol. 33 , no. 2 , pp. 53-64.

[8] D. R. Gehart, D. Ratliff, and R. R. Lyle, "Qualitative research in family therapy: A substantive and methodological review," Journal of Marital and Family Therapy. 2001.

[9] D. Goodley and P. Clough, "Community projects and excluded young people: Reflections on a participatory narrative research approach,” Int. J. Incl. Educ., vol. 8, no. 4, pp. 331-351, 2004.

[10] D. Goodley, "Learning difficulties', the social model of disability and impairment: challenging epistemologies," Disabil. Soc., vol. 16, no. 2, pp. 207-231, 2001.

[11] D. Widagdho, "Ilmu Budaya Dasar, Cetakan Kesembilan." Jakarta, PT. Bumi Aksara, 2004.

[12] Koentjaraningrat, Kebudayaan, mentalitet, dan pembangunan: bungarampai. Gramedia, 1974.

[13] R. M. Koentjaraningrat, Manusia dan kebudajaan di Indonesia. Djambatan, 1970

[14] R. L. Mathis and J. H. Jackson, Manajemen sumber daya manusia. Thomson Learning, 2001
[15] M. Amin, "Hubungan Antara Budaya Kerja dan Motivasi Kerja dengan Kinerja Guru di MTs N 1 Lampung Selatan Kabupaten Lampung Selatan.” UIN Raden Intan Lampung, 2017.

[16] H. Mulyadi, "Implementasi 5 Nilai Budaya Kerja Kementerian Agama dalam meningkatkan kinerja pegawai Seksi Pendidikan Agama dan Keagamaan Islam Kantor Kementerian Agama Kabupaten Lampung Barat.” UIN Raden Intan Lampung, 2017.

[17] T. Ndraha, "Teori Budaya Organisasi, Cetakan Kedua," Jakarta PT. Rineka Cipta, 2003.

[18] N. Nurnaningsih, "Pendidikan kepribadian dalam Pangadereng: naskah Latoa asimilasi dengan nilai-nilai Islam," Lentera Pendidik. J. Ilmu Tarb. dan Kegur., vol. 18, no. 1, pp. 43-55, 2015.

[19] H. M. B. A. Teng, "Pappaseng to Riolo, Falsafah Hidup Orang Bugis: Dalam Perspektif Sejarah," Penguatan Budaya Lokal Sebagai Peneguh Multikulturalisme Melalui Toler. Budaya, p. 21.

[20] P. Hamid, T. Kartikasari, S. Sumardi, and S. Mintosih, Lotarak Tellumpoccoe. Departemen Pendidikan dan Kebudayaan, Direktorat Jenderal Kebudayaan ..., 1992.

[21] I. Abbas, "Pappaseng: Kearifan Lokal Manusia Bugis yang Terlupakan," Sosiohumaniora, 2013.

[22] M. Rapi Tang, "Tolak Rumpana Bone." Jakarta: Pusat Pembinaan dan Pengembagan Bahasa Depdiknas, 2000. 